\title{
Potential of Plant Growth Promoting Bacteria on Nutrient Availability in Soil, Nutrient Uptake and Yield of Summer Groundnut Grown on Entisol
}

\author{
A.D. Raut*, A.G. Durgude, A.D. Kadlag, M.V.V.I. Annapurna and M.R. Chauhan \\ Department of Soil Science and Agricultural Chemistry, Mahatma Phule Krishi Vidyapeeth, \\ Rahuri, 413722, Maharashtra \\ *Corresponding author
}

\section{Ke y w o r d s \\ $\mathrm{ZnSB}$, GRDF, \\ $\mathrm{ZnSO} 4, \mathrm{ZnO}$, \\ Available nutrients, \\ Total nutrients, \\ yield}

Article Info

Accepted:

18 January 2019

Available Online:

10 February 2019

\section{A B S T R A C T}

A field experiment was conducted during the year 2017-18 at Post Graduate Institute Farm, Mahatma Phule Krishi Vidyapeeth, Rahuri. The experiment was laid out in Randomised block design with three replication and eleven treatments. The treatments comprised of $\mathrm{T}_{1}$ : Absolute control, $\mathrm{T}_{2}$ : only ZnSB, $\mathrm{T}_{3}: \operatorname{GRDF}\left(25: 50 \mathrm{~kg} \mathrm{ha}^{-1} \mathrm{~N}: \mathrm{P}_{2} \mathrm{O}_{5}+\right.$ FYM@ $\left.5 \mathrm{t} \mathrm{ha}^{-1}\right), \mathrm{T}_{4}$ to $\mathrm{T}_{7}$ were GRDF + 100\%,75\%, 50\% and 25\% RD of $\mathrm{Zn}$ through $\mathrm{ZnSO}_{4}+\mathrm{ZnSB}$ and $\mathrm{T}_{8}$ to $\mathrm{T}_{11}$ were GRDF $+100 \%, 75 \%, 50 \%$ and $25 \% \mathrm{RD}$ of $\mathrm{Zn}$ through $\mathrm{ZnO}+\mathrm{ZnSB}$. The biofertilizer zinc solubilizing bacteria was given as a seed treatment as well as soil drenching @ 5\% at 30 days of sowing. The soil pH, EC, organic carbon and calcium carbonate content in soil at initial as well as at harvest did not find any differences amongst treatments. The available $\mathrm{N}, \mathrm{P}$ and $\mathrm{K}$ status of soil at harvest were found to be significantly improved due to application of $100 \% \mathrm{Zn}$ through $\mathrm{ZnSO}_{4}$ along with $\mathrm{ZnSB}$ and GRDF. The DTPA-Fe, $\mathrm{Zn}, \mathrm{Mn}$ and $\mathrm{Cu}$ status of soil at harvest was also found to be significantly increased due to application of $100 \% \mathrm{Zn}$ through $\mathrm{ZnSO}_{4}+$ GRDF. Total uptake of nitrogen, phosphorus and potassium by groundnut crop was significantly increased (132.29, 15.60 and $65.63 \mathrm{~kg} \mathrm{ha}^{-1}$, respectively) due to application of $100 \% \mathrm{Zn}$ through $\mathrm{ZnSO}_{4}+\mathrm{ZnSB}$ along with GRDF. The same trend was also observed in above treatment in respect of total uptake of Fe, $\mathrm{Zn}, \mathrm{Mn}$ and $\mathrm{Cu}\left(1352,377,619\right.$ and $67 \mathrm{~g} \mathrm{ha}^{-1}$, respectively). The oil per cent was significantly increased in treatment of $\mathrm{T}_{4}(40.96 \%)$ over all the treatment. The pod yield of groundnut was significantly increased in treatment of $\mathrm{T}_{4}\left(30.63 \mathrm{q} \mathrm{ha}^{-1}\right)$ over all the treatments except treatment $\mathrm{T}_{5}\left(29.44 \mathrm{q} \mathrm{ha}^{-1}\right)$ which was at par with $\mathrm{T}_{4}$. Haulm yield of groundnut was significantly increased $\left(62.70 \mathrm{q} \mathrm{ha}^{-1}\right)$ in treatment of $\mathrm{T}_{3}\left(100 \%\right.$ GRDF (25:50:00 kg ha-1 N:P $\left.\mathrm{P}_{2} \mathrm{O}_{5}+\mathrm{FYM} @ 5 \mathrm{tha}^{-1}\right)$ over all the treatments. It can be thus concluded that, the application of $100 \%$ recommended dose of Zn through Zinc sulphate @ $20 \mathrm{~kg} \mathrm{ha}^{-1}+5 \% \mathrm{ZnSB}$ to seed treatment at sowing and through drenching at 30 DAS along with $100 \%$ recommended dose of nutrients $(25: 50 \mathrm{~kg}$ $\mathrm{ha}^{-1} \mathrm{~N}: \mathrm{P}_{2} \mathrm{O}_{5}+\mathrm{FYM} @ 5 \mathrm{tha}^{-1}$ ) to summer groundnut was found beneficial for increased in available macro and micronutrients status of soil, total uptake of macro and micronutrient. 


\section{Introduction}

India is blessed with the agro-ecological condition favourable for growing nine major oilseeds including seven edible oilseed namely groundnut, rapeseed, mustard, soybean, sunflower, safflower, sesame and niger and two non-edible sources, namely castor and linseed, apart from wide range of other minor oilseeds and oil bearing species. Among all the oilseed crops, groundnut occupies the first place in India accounting for more than $28 \%$ of acreage and $32 \%$ of production in the country. However, except for castor, the productivity of oilseed crops in India is one of the lowest in the world.

Groundnut or peanuts originated in South America. Groundnut is grown in five states namely Andhra Pradesh, Gujarat, Tamilnadu, Karnataka and Maharashtra and together they account for about $90 \%$ per cent of the cultivated area. Andhra Pradesh and Gujarat states share about 28 and 24 per cent of the total cultivated area, respectively. About $8 \%$ of the total groundnut area is in the state of Maharashtra.

Zinc is one of the most important micronutrients. It plays vital role in the plant life. It has vital role in transformation of carbohydrates, regulation of consumption of sugar and increase source of energy for the production of chlorophyll. Zinc is also required for maintenance of auxin in an active state. The zinc is essential for the synthesis of tryptophan a precursor of auxin. Zinc deficiency in groundnut crop causes chlorotic strips on leaves and this band on the leaf portion nearest to petiole. Also it result in stunted growth while, the young leaves smaller than normal. This deficiency similar to iron deficiency only the difference is that chlorosis occur full length of the leaves and in peanut lower half of the leaves.

Among the bacterial species, strains belonging to the genera Acinetobacter,
Bacillus, Gluconacetobacter and Pseudomonas have been reported (Simine Di et al., 1998; Fasim et al., 2002; Saravanan et al., 2007) as zinc solubilizers, fertilizers and manures, to enhance soil fertility and crop productivity has often negatively affected the complex biogeochemical cycles (Perrott et al.,1992; Steinshamn et al., 2004). Continuous application of fertilizers as well as their low use efficiency has caused leaching and runoff of nutrients, especially $\mathrm{N}$ and $\mathrm{P}$ leading to environmental degradation (Tilman, 1998 and Gyaneshwar et al., 2002). On the other hand, high cost associated with the application of $\mathrm{Zn}$ fertilizers in order to correct $\mathrm{Zn}$ deficiency places considerable burden on resource poor farmers (Wissuwa $e t$ al., 2006). One of the possible ways to increase crop productivity as well as food quality without creating the environmental issues is by the use of plant growth promoting rhizobacteria (PGPR). The PGPR were capable of colonizing the rhizosphere, root surface and internal tissues in plants. The main microbial mechanisms by which PGPR improved plant growth include $\mathrm{N}$-fixation, inorganic $\mathrm{P}$ solubilisation, siderophore production, phytohormone synthesis and by controlling plant pathogens (Lugtenberg and Kamilova, 2009). Different plant growth promoting bacteria including free living and associative such as Azospirillum, Azotobacter, Bacillus and Pseudomonas have been used in agricultural systems as biofertiloops. Various crizers for their beneficial effects on plant growth (Tilak et al., 1982). Hitchins et al., (1986) reported that Thiobacillus thioxidance, T. ferroxidance and facultative thermophilic iron oxidizers solubilized zinc from sulphideore (sphalerite). Exogenous application of zinc sources, similar to fertilizer application has been advocated to various crops. This causes transformation of about 96 to 99 per cent of applied available zinc to various unavailable forms. The zinc thus, made unavailable can be reverted back 
to available form by inoculating bacterial strain capable of solubilizing it. Since zinc is a limiting factor in crop production, this study on zinc solubilization by bacteria has an immense importance in zinc nutrition to plant.

\section{Materials and Methods}

The field experiment was conducted on groundnut (CV: TG - 26) during Summer in 2016-17 in randomized block design with three replication on the soil belonging to order Entisol (Typic Ustorthent) at Post Graduate Institute, Mahatma Phule Agricultural University, Rahuri, Maharashtra, located between $19^{0} 34^{\prime} \mathrm{N}$ latitude and $74^{\circ} 64^{\prime} \mathrm{E}$ longitude. The treatment comprised of $\mathrm{T}_{1}$ : Absolute control, $\mathrm{T}_{2}$ : only $\mathrm{ZnSB}, \mathrm{T}_{3}$ : GRDF(25:50 kg ha ${ }^{-1} \mathrm{~N}: \mathrm{P}_{2} \mathrm{O}_{5}+\mathrm{FYM} @ 5 \mathrm{tha}$ $\left.{ }^{1}\right), \mathrm{T}_{4}$ to $\mathrm{T}_{7}$ were GRDF $+100 \%, 75 \%, 50 \%$ and $25 \% \mathrm{RD}$ of $\mathrm{Zn}$ through $\mathrm{ZnSO}_{4}+\mathrm{ZnSB}$ and $\mathrm{T}_{8}$ to $\mathrm{T}_{11}$ were GRDF $+100 \%, 75 \%$, $50 \%$ and $25 \% \mathrm{RD}$ of $\mathrm{Zn}$ through $\mathrm{ZnO}+$ $\mathrm{ZnSB}$. ZnSB was given through seed treatment at the time of sowing @ 5\% and second $5 \% \mathrm{ZnSB}$ was given by drenching in soil at 30 DAS. The experimental soil for groundnut crop had $\mathrm{pH}, 8.16, \mathrm{EC}, 0.28 \mathrm{dSm}^{-1}$, Org. C, $0.44 \%, \mathrm{CaCO}_{3}, 5.41 \%$, Available N, $205 \mathrm{~kg} \mathrm{ha}{ }^{-1}$, Available P,13.8 $\mathrm{kg} \mathrm{ha}^{-1}$, Available K, $410 \mathrm{~kg} \mathrm{ha}^{-1}$, DTPA-Fe $4.02 \mathrm{mg}$ $\mathrm{kg}^{-1}$, Mn $10.70 \mathrm{mg} \mathrm{kg}^{-1}$, Zn $0.49 \mathrm{mg} \mathrm{kg}^{-1}$ and $\mathrm{Cu} 1.92 \mathrm{mg} \mathrm{kg}^{-1}$. The seed of groundnut was coated with a consortia of zinc solubilizing bacteria culture viz., Bacillus polymyxa, Bacillus megaterium, Pseudomonas striata, Pseudomonas fluroscence, Gluconoacetobacter diazotrophicus and Aspergillus awamori. The recommended dose of $\mathrm{N}: \mathrm{P}_{2} \mathrm{O}_{5}: \mathrm{K}_{2} \mathrm{O} @ 25: 50: 00 \mathrm{~kg} \mathrm{ha}^{-1}$ was applied to groundnut. The soil samples were collected before sowing and harvest of groundnut analysed as perstandard methods. The plant and pod samples were analysed for Total $\mathrm{N}$ by micro-Kjedahl method (Jackson 1958), Total P by vanodomolybdate yellow colour method (Chapman and Pratt 1961) in diacid mixture of $\mathrm{HNO}_{3}: \mathrm{HCLO}_{4}(9: 4)$ and Total K by Flame photometer (Chapman and Pratt, 1961) in $\mathrm{HNO}_{3}: \mathrm{HCLO}_{4}(9: 4)$.

\section{Results and Discussion}

\section{Soil chemical properties}

The data regarding chemical properties of groundnut revealed that (Table 1) there was no significant differences in case of $\mathrm{pH}, \mathrm{EC}$, Org. $\mathrm{C}$ and $\mathrm{CaCO}_{3}$ due to different treatment combinations.

\section{Soil available nutrients}

Soil available nitrogen content at initial stage was low in status $\left(143 \mathrm{~kg} \mathrm{ha}^{-1}\right)$, however, at harvest was significantly increased in treatment of $\mathrm{T}_{4}\left(198 \mathrm{~kg} \mathrm{ha}^{-1}\right)$ over all the treatments except $T_{9}\left(192 \mathrm{~kg} \mathrm{ha}^{-1}\right)$, which was at par with treatment $T_{4}$, Overall, available nitrogen status showed low in soil at harvest. The increase in the available nitrogen content in soil at harvest might be due to $100 \%$ fertilizer nitrogen dose and $100 \% \mathrm{RD}$ of $\mathrm{Zn}$ through $\mathrm{ZnSO}_{4}$ along with $\mathrm{ZnSB}$. Similar results were also reported by Kayalvizhi et al., (2001) in sugarcane and Kumar et al., (2004) (Table 2).

Available phosphorus in soil at initial showed low status (10.89 $\mathrm{kg} \mathrm{ha}^{-1}$ ), however, at harvest, it significantly increased in treatment $\mathrm{T}_{4}\left(11.02 \mathrm{~kg} \mathrm{ha}^{-1}\right)$ over all the treatments. This might be due to increased in $\mathrm{P}$ use efficiency by the application of $\mathrm{ZnSO}_{4} @ 20 \mathrm{~kg} \mathrm{ha}^{-1}$ in soil + ZnSB along with 100\% GRDF. Overall, available $\mathrm{P}$ showed low status in soil at harvest in all the treatment under study, which might be due to higher fixation of $\mathrm{P}$ under alkaline condition. Low phosphorus availability in calcareous soil might be due to their transformation to more complicated forms with $\mathrm{CaCO}_{3}$ and these changed forms 
are rendered less available to growing plants. Similar results were also recorded by Bashour et al., (1983). The effect of low P solubility in alkaline and calcareous soil was due to poor fertilizer $\mathrm{P}$ efficiency. The similar results were also supported by Stark and Westermann (2003) and Javid and Rowell (2003).

Available potassium content in soil at initial stage was medium status (185 $\left.\mathrm{kg} \mathrm{ha}^{-1}\right)$, however, at harvest the treatment $\mathrm{T}_{4}$ was found to be significantly increased $(198 \mathrm{~kg}$ ha $^{-1}$ ) over all the treatment $T_{3}, T_{4}, T_{5}, T_{6}, T_{7}$, $\mathrm{T}_{9}, \mathrm{~T}_{10}$ and $\mathrm{T}_{11}$ except treatment $\mathrm{T}_{2}$ and $\mathrm{T}_{8}$ which were at par. Overall, available potassium showed medium status at harvest in all the treatment under study.

\section{Soil available micronutrients}

DTPA micronutrients content in soil at soil $\mathrm{Zn}$, However, sufficient in available $\mathrm{Mn}$ and $\mathrm{Cu}$. The soils were deficient in DTPA- iron as the critical limit of DTPA-iron is $4.5 \mathrm{ppm}$. The soil available $\mathrm{Fe}$ at initial stage was deficient $\left(4.11 \mathrm{mg} \mathrm{kg}^{-1}\right)$, however, at harvest it showed significantly higher content in treatment of $T_{4}\left(3.91 \mathrm{mg} \mathrm{kg}^{-1}\right)$ over $T_{1}, T_{3}, T_{7}$, $\mathrm{T}_{10}$ and $\mathrm{T}_{11}$ treatment however, treatment $\mathrm{T}_{4}$ were at par with treatments of $\mathrm{T}_{2}, \mathrm{~T}_{5}, \mathrm{~T}_{6}, \mathrm{~T}_{8}$ and $\mathrm{T}_{9}$. The same trend of increasing in micronutrients status was observed at harvest stage with slight decrease in the values which may be due to uptake of micronutrients. Similar results have been reported by Stein (2010) (Table 3).

The soil of experimental site was deficient in available $\mathrm{Zn}\left(0.35 \mathrm{mg} \mathrm{kg}^{-1}\right)$ as the critical limit of DTPA-Zn in soil is $0.6 \mathrm{ppm}$. At harvest, available $\mathrm{Zn}$ in soil found to be significantly increased in $\mathrm{T}_{4}\left(0.58 \mathrm{mg} \mathrm{kg}^{-1}\right)$ over all the treatment. The increase in DTPA$\mathrm{Zn}$ content in soil was slightly higher in treatments of application of $\mathrm{ZnSO}_{4}$ as compared to $\mathrm{ZnO}$ treatments along with seed treatment and soil drenching treatment of ZnSB @ 5\%. Similar results were also reported by Fasim et al., (2002).

The soil available Mn content at initial and at harvest, it showed non significant results. The soil available $\mathrm{Cu}$ content at initial showed sufficient status $\left(1.82 \mathrm{mg} \mathrm{kg}^{-1}\right)$, however, at harvest it did not influenced. Application of $\mathrm{ZnSO}_{4}$ fertilizer treatment showed the higher values of DTPA-Cu in soil as compared to application of $\mathrm{ZnO}$ fertilizer, it may be due to limited solubility of $\mathrm{ZnO}$ fertilizer in soil.

\section{Nutrient uptake by groundnut}

The effect of application of zinc fertilizer and zinc solubilizing bacteria on total nutrient uptake of $\mathrm{N}, \mathrm{P}$ and $\mathrm{K}$ as influenced by different treatments are presented in table 4 .

The data in respect of total nitrogen uptake by groundnut was found significant results. However, treatment $\mathrm{T}_{4}$ showed higher uptake of total $\mathrm{N}\left(132.29 \mathrm{~kg} \mathrm{ha}^{-1}\right)$ over all the treatment. Higher uptake of nitrogen was due to application of $\mathrm{ZnSO}_{4}$ and use of $\mathrm{ZnSB}$ as a seed treatment and drenching treatment. Potarzycki and Grzebisz (2009) also reported similar result that zinc exerts a great influence on basic plant life processes such as nitrogen metabolism and uptake of nitrogen.

The highest total $\mathrm{P}$ uptake by groundnut plant was significantly found to be observed in treatment of $T_{4}\left(15.60 \mathrm{~kg} \mathrm{ha}^{-1}\right)$ over all the treatment except total uptake of $\mathrm{P}$ in treatment $\mathrm{T}_{3}$ which was at par with $\mathrm{T}_{4}$. This is because of soil application of $\mathrm{ZnSO}_{4}$ @ $20 \mathrm{~kg} \mathrm{ha}^{-1}$ with $\mathrm{ZnSB}$ increased the availability of $\mathrm{P}$ in soil. These finding are in consonance with Manna et al., (2007) who reported that the activity of alkaline phosphates was significantly increased with increase in FYM levels and PSM inoculation resulting more 
solubilization of $\mathrm{P}$ and uptake by soybean plant. The total $\mathrm{K}$ uptake by groundnut was significantly higher in $\mathrm{T}_{4}$ treatment $(65.63 \mathrm{~kg}$ $\mathrm{ha}^{-1}$ ) over all the treatment. The increase in total $\mathrm{N}$ and $\mathrm{K}$ uptake could be attributed to synergistic effect between $\mathrm{N}$ and $\mathrm{Zn}$ and due to the positive interaction of $\mathrm{K}$ and $\mathrm{Zn}$, respectively. The present findings support the results of Ashoka et al., (2008), Morshedi and Farahbakhsh (2010).

\section{Total micronutrients}

The total uptake of $\mathrm{Fe}, \mathrm{Zn}, \mathrm{Mn}$ and $\mathrm{Cu}$ by groundnut as influenced by different treatment are presented in table 5 .

Table.1 Effect of zinc fertilizer and zinc solubilizing bacteria on soil properties

\begin{tabular}{|c|c|c|c|c|c|}
\hline $\begin{array}{l}\text { Tr. } \\
\text { No }\end{array}$ & Treatment & $\begin{array}{c}\text { pH } \\
(1: 2.5)\end{array}$ & $\underset{\left(\mathbf{d S m}^{-1}\right)}{\mathbf{E C}}$ & $\begin{array}{c}\text { Organic } \\
\text { carbon }(\%)\end{array}$ & $\begin{array}{c}\mathrm{CaCO}_{3} \\
(\%)\end{array}$ \\
\hline$T_{1}:$ & Absolute control & 8.17 & 0.26 & 0.40 & 5.40 \\
\hline $\mathbf{T}_{2}:$ & ZnSB alone & 8.14 & 0.24 & 0.41 & 5.41 \\
\hline $\mathbf{T}_{3}:$ & 100\% GRDF (25:50 kg ha $\left.{ }^{-1} \mathrm{~N}: \mathrm{P}_{2} \mathrm{O}_{5} \mathrm{FYM}+@ 5 \mathrm{t} \mathrm{ha}^{-1}\right)$ & 8.06 & 0.27 & 0.49 & 5.54 \\
\hline $\mathbf{T}_{4}:$ & $\mathrm{T}_{3}+100 \% \mathrm{RD}$ of $\mathrm{Zn}$ through Zinc sulphate $\mathrm{ZnSB}$ & 8.02 & 0.30 & 0.50 & 5.33 \\
\hline$T_{5}:$ & $\mathrm{T}_{3}+75 \% \mathrm{RD}$ of $\mathrm{Zn}$ through Zinc sulphate $+\mathrm{ZnSB}$ & 8.04 & 0.28 & 0.48 & 5.17 \\
\hline$T_{6}:$ & $\mathrm{T}_{3}+50 \% \mathrm{RD}$ of $\mathrm{Zn}$ through Zinc sulphate $+\mathrm{ZnSB}$ & 8.04 & 0.27 & 0.46 & 5.21 \\
\hline $\mathbf{T}_{7}:$ & $\mathrm{T}_{3}+25 \% \mathrm{RD}$ of $\mathrm{Zn}$ through Zinc sulphate $+\mathrm{ZnSB}$ & 8.08 & 0.25 & 0.44 & 5.08 \\
\hline$T_{8}:$ & $\mathrm{T}_{3}+100 \% \mathrm{RD}$ of $\mathrm{Zn}$ through Zinc oxide $+\mathrm{ZnSB}$ & 8.16 & 0.26 & 0.46 & 5.71 \\
\hline $\mathbf{T}_{9}:$ & $\mathrm{T}_{3}+75 \% \mathrm{RD}$ of $\mathrm{Zn}$ through Zinc oxide $+\mathrm{ZnSB}$ & 8.16 & 0.27 & 0.44 & 5.75 \\
\hline $\mathbf{T}_{10}:$ & $\mathrm{T}_{3}+50 \% \mathrm{RD}$ of $\mathrm{Zn}$ through Zinc oxide $+\mathrm{ZnSB}$ & 8.14 & 0.28 & 0.48 & 5.87 \\
\hline $\mathbf{T}_{11}$ : & $\mathrm{T}_{3}+25 \% \mathrm{RD}$ of $\mathrm{Zn}$ through Zinc oxide $+\mathrm{ZnSB}$ & 8.16 & 0.27 & 0.49 & 5.08 \\
\hline \multicolumn{2}{|c|}{ S.E.m \pm} & 0.016 & 0.011 & 0.013 & 0.023 \\
\hline \multicolumn{2}{|c|}{ CD at $5 \%$} & NS & NS & NS & NS \\
\hline
\end{tabular}

Table.2 Effect of zinc fertilizer and zinc solubilizing bacteria on residual soil available nitrogen, phosphorus and potassium

\begin{tabular}{|c|c|c|c|c|}
\hline $\begin{array}{l}\text { Tr. } \\
\text { No }\end{array}$ & Treatment & $\begin{array}{c}\text { Av. } \mathbf{N} \\
\left(\mathrm{kg} \mathrm{ha}^{-1}\right)\end{array}$ & $\underset{\left(\mathrm{kg} \mathrm{ha}^{-1}\right)}{\text { Av. P }}$ & $\begin{array}{c}\text { Av. K } \\
\left(\mathrm{kg} \mathrm{ha}^{-1}\right)\end{array}$ \\
\hline$T_{1}:$ & Absolute control & 178 & 9.12 & 171 \\
\hline $\mathbf{T}_{2}:$ & ZnSB alone & 170 & 8.95 & 182 \\
\hline $\mathbf{T}_{3}:$ & 100\% GRDF (25:50 kg ha $\left.{ }^{-1} \mathrm{~N}: \mathrm{P}_{2} \mathrm{O}_{5} \mathrm{FYM}+@ 5 \mathrm{tha}^{-1}\right)$ & 186 & 9.78 & 190 \\
\hline $\mathbf{T}_{4}:$ & $\mathrm{T}_{3}+100 \% \mathrm{RD}$ of $\mathrm{Zn}$ through Zinc sulphate $\mathrm{ZnSB}$ & 198 & 11.02 & 198 \\
\hline $\mathbf{T}_{5}:$ & $\mathrm{T}_{3}+75 \% \mathrm{RD}$ of $\mathrm{Zn}$ through Zinc sulphate $+\mathrm{ZnSB}$ & 184 & 9.51 & 184 \\
\hline $\mathbf{T}_{6}:$ & $\mathrm{T}_{3}+50 \% \mathrm{RD}$ of $\mathrm{Zn}$ through Zinc sulphate $+\mathrm{ZnSB}$ & 180 & 9.24 & 186 \\
\hline $\mathbf{T}_{7}:$ & $\mathrm{T}_{3}+25 \% \mathrm{RD}$ of $\mathrm{Zn}$ through Zinc sulphate $+\mathrm{ZnSB}$ & 174 & 8.96 & 180 \\
\hline$T_{8}:$ & $\mathrm{T}_{3}+100 \% \mathrm{RD}$ of $\mathrm{Zn}$ through Zinc oxide $+\mathrm{ZnSB}$ & 190 & 9.46 & 190 \\
\hline$T_{9}:$ & $\mathrm{T}_{3}+75 \% \mathrm{RD}$ of $\mathrm{Zn}$ through Zinc oxide $+\mathrm{ZnSB}$ & 192 & 8.24 & 178 \\
\hline $\mathbf{T}_{10}:$ & $\mathrm{T}_{3}+50 \% \mathrm{RD}$ of $\mathrm{Zn}$ through Zinc oxide $+\mathrm{ZnSB}$ & 190 & 8.92 & 180 \\
\hline $\mathbf{T}_{11}:$ & $\mathrm{T}_{3}+25 \% \mathrm{RD}$ of $\mathrm{Zn}$ through Zinc oxide $+\mathrm{ZnSB}$ & 180 & 8.98 & 174 \\
\hline \multicolumn{2}{|c|}{ S.E.m \pm} & 2.32 & 0.047 & 3.724 \\
\hline \multicolumn{2}{|c|}{ CD at $5 \%$} & 6.92 & 0.14 & 10.98 \\
\hline
\end{tabular}


Table.3 Effect of zinc fertilizer and zinc solubilizing bacteria on available micronutrient content in soil $\left(\mathrm{mg} \mathrm{kg}^{-1}\right)$

\begin{tabular}{|c|c|c|c|c|c|}
\hline $\begin{array}{l}\text { Tr. } \\
\text { No }\end{array}$ & Treatment & $\begin{array}{c}\text { DTPA- } \\
\text { Fe }\end{array}$ & $\begin{array}{c}\text { DTPA- } \\
\text { Zn }\end{array}$ & $\begin{array}{l}\text { DTPA- } \\
\text { Mn }\end{array}$ & $\begin{array}{c}\text { DTPA- } \\
\text { Cu }\end{array}$ \\
\hline $\mathbf{T}_{1}:$ & Absolute control & 3.82 & 0.40 & 5.16 & 1.21 \\
\hline$T_{2}:$ & ZnSB alone & 3.88 & 0.46 & 5.20 & 1.30 \\
\hline $\mathbf{T}_{3}:$ & $100 \%$ GRDF $\left(25: 50 \mathrm{~kg} \mathrm{ha}^{-1} \mathrm{~N}: \mathrm{P}_{2} \mathrm{O}_{5} \mathrm{FYM}+@ 5 \mathrm{tha}^{-1}\right)$ & 3.80 & 0.52 & 5.89 & 1.26 \\
\hline $\mathbf{T}_{4}:$ & $\mathrm{T}_{3}+100 \% \mathrm{RD}$ of $\mathrm{Zn}$ through Zinc sulphate $\mathrm{ZnSB}$ & 3.91 & 0.58 & 5.17 & 1.44 \\
\hline $\mathbf{T}_{5}:$ & $\mathrm{T}_{3}+75 \% \mathrm{RD}$ of $\mathrm{Zn}$ through Zinc sulphate $+\mathrm{ZnSB}$ & 3.86 & 0.54 & 5.81 & 1.39 \\
\hline$T_{6}:$ & $\mathrm{T}_{3}+50 \% \mathrm{RD}$ of $\mathrm{Zn}$ through Zinc sulphate $+\mathrm{ZnSB}$ & 3.88 & 0.51 & 5.58 & 1.38 \\
\hline $\mathbf{T}_{7}:$ & $\mathrm{T}_{3}+25 \% \mathrm{RD}$ of $\mathrm{Zn}$ through Zinc sulphate $+\mathrm{ZnSB}$ & 3.74 & 0.48 & 5.73 & 1.38 \\
\hline$T_{8}:$ & $\mathrm{T}_{3}+100 \% \mathrm{RD}$ of $\mathrm{Zn}$ through Zinc oxide $+\mathrm{ZnSB}$ & 3.90 & 0.50 & 5.12 & 1.41 \\
\hline $\mathbf{T}_{9}:$ & $\mathrm{T}_{3}+75 \% \mathrm{RD}$ of $\mathrm{Zn}$ through Zinc oxide $+\mathrm{ZnSB}$ & 3.87 & 0.48 & 5.05 & 1.32 \\
\hline$T_{10}:$ & $\mathrm{T}_{3}+50 \% \mathrm{RD}$ of $\mathrm{Zn}$ through Zinc oxide $+\mathrm{ZnSB}$ & 3.80 & 0.46 & 5.75 & 1.28 \\
\hline$T_{11}:$ & $\mathrm{T}_{3}+25 \% \mathrm{RD}$ of $\mathrm{Zn}$ through Zinc oxide $+\mathrm{ZnSB}$ & 3.81 & 0.49 & 5.60 & 1.30 \\
\hline \multicolumn{2}{|c|}{ S.E.m \pm} & 0.02 & 0.01 & 0.38 & 0.046 \\
\hline \multicolumn{2}{|c|}{ CD at $5 \%$} & 0.06 & 0.03 & NS & NS \\
\hline
\end{tabular}

Table.4 Effect of zinc fertilizer and zinc solubilizing bacteria on Total nutrient uptake (kg ha-1)

\begin{tabular}{|c|c|c|c|c|}
\hline \multirow[t]{2}{*}{$\begin{array}{l}\text { Tr. } \\
\text { No }\end{array}$} & \multirow[t]{2}{*}{ Treatment } & \multicolumn{3}{|c|}{$\begin{array}{l}\text { Total uptake of macronutrient } \\
\qquad\left(\mathrm{kg} \mathrm{ha}^{-1}\right)\end{array}$} \\
\hline & & $\mathbf{N}$ & $\mathbf{P}$ & $\mathbf{K}$ \\
\hline $\mathbf{T}_{1}$ & Absolute control & 72.80 & 9.81 & 44.40 \\
\hline $\mathbf{T}_{2}$ & ZnSB alone & 93.40 & 11.66 & 47.51 \\
\hline $\mathbf{T}_{3}$ & 100\% GRDF (25:50kg ha $\left.{ }^{-1} \mathrm{~N}: \mathrm{P}_{2} \mathrm{O}_{5}+\mathrm{FYM} @ 5 \mathrm{t} \mathrm{ha}^{-1}\right)$ & 114.62 & 15.19 & 62.18 \\
\hline $\mathbf{T}_{4}$ & $\mathrm{~T}_{3}+100 \% \mathrm{RD}$ of $\mathrm{Zn}$ through Zinc sulphate $+\mathrm{ZnSB}$ & 132.29 & 15.60 & 65.63 \\
\hline $\mathbf{T}_{5}$ & $\mathrm{~T}_{3}+75 \%$ RD of Zn through Zinc sulphate $+\mathrm{ZnSB}$ & 119.27 & 14.26 & 54.51 \\
\hline $\mathbf{T}_{6}$ & $\mathrm{~T}_{3}+50 \% \mathrm{RD}$ of $\mathrm{Zn}$ through Zinc sulphate $+\mathrm{ZnSB}$ & 91.12 & 13.73 & 50.71 \\
\hline $\mathbf{T}_{7}$ & $\mathrm{~T}_{3}+25 \% \mathrm{RD}$ of $\mathrm{Zn}$ through Zinc sulphate $+\mathrm{ZnSB}$ & 94.77 & 12.41 & 49.97 \\
\hline $\mathbf{T}_{8}$ & $\mathrm{~T}_{3}+100 \% \mathrm{RD}$ of $\mathrm{Zn}$ through Zinc oxide $+\mathrm{ZnSB}$ & 105.64 & 14.50 & 50.77 \\
\hline $\mathbf{T}_{9}$ & $\mathrm{~T}_{3}+75 \% \mathrm{RD}$ of $\mathrm{Zn}$ through Zinc oxide $+\mathrm{ZnSB}$ & 105.59 & 13.38 & 51.50 \\
\hline $\mathbf{T}_{10}$ & $\mathrm{~T}_{3}+50 \% \mathrm{RD}$ of $\mathrm{Zn}$ through Zinc oxide $+\mathrm{ZnSB}$ & 100.03 & 11.97 & 50.71 \\
\hline $\mathbf{T}_{11}$ & $\mathrm{~T}_{3}+25 \% \mathrm{RD}$ of $\mathrm{Zn}$ through Zinc oxide $+\mathrm{ZnSB}$ & 84.60 & 11.33 & 49.17 \\
\hline \multicolumn{2}{|c|}{ S.E.m \pm} & 19.90 & 1.405 & 0.419 \\
\hline \multicolumn{2}{|c|}{ CD at $5 \%$} & 59.11 & 4.175 & 1.245 \\
\hline
\end{tabular}


Table.5 Effect of zinc fertilizer and zinc solubilizing bacteria on Total micronutrient uptake $\left(\mathrm{g} \mathrm{ha}^{-1}\right)$

\begin{tabular}{|c|c|c|c|c|c|}
\hline \multirow[t]{2}{*}{$\begin{array}{l}\text { Tr. } \\
\text { No }\end{array}$} & \multirow[t]{2}{*}{ Treatment } & \multicolumn{4}{|c|}{$\begin{array}{l}\text { Total uptake of micronutrient } \\
\qquad\left(\mathrm{g} \mathrm{ha}^{-1}\right)\end{array}$} \\
\hline & & Fe & Zn & Mn & $\mathbf{C u}$ \\
\hline $\mathbf{T}_{1}$ & Absolute control & 897 & 207 & 401 & 36 \\
\hline $\mathbf{T}_{2}$ & ZnSB alone & 972 & 235 & 431 & 43 \\
\hline $\mathbf{T}_{\mathbf{3}}$ & 100\% GRDF (25:50kg ha $\left.{ }^{-1} \mathrm{~N}: \mathrm{P}_{2} \mathrm{O}_{5}+\mathrm{FYM@} 5 \mathrm{t} \mathrm{ha}^{-1}\right)$ & 1344 & 307 & 598 & 53 \\
\hline $\mathbf{T}_{4}$ & $\mathrm{~T}_{3}+100 \% \mathrm{RD}$ of $\mathrm{Zn}$ through Zinc sulphate $+\mathrm{ZnSB}$ & 1352 & 377 & 619 & 67 \\
\hline $\mathbf{T}_{5}$ & $\mathrm{~T}_{3}+75 \% \mathrm{RD}$ of $\mathrm{Zn}$ through Zinc sulphate $+\mathrm{ZnSB}$ & 1213 & 336 & 504 & 61 \\
\hline $\mathbf{T}_{6}$ & $\mathrm{~T}_{3}+50 \% \mathrm{RD}$ of $\mathrm{Zn}$ through Zinc sulphate $+\mathrm{ZnSB}$ & 1107 & 292 & 485 & 48 \\
\hline $\mathbf{T}_{7}$ & $\mathrm{~T}_{3}+25 \% \mathrm{RD}$ of $\mathrm{Zn}$ through Zinc sulphate $+\mathrm{ZnSB}$ & 1051 & 265 & 457 & 47 \\
\hline $\mathbf{T}_{8}$ & $\mathrm{~T}_{3}+100 \% \mathrm{RD}$ of $\mathrm{Zn}$ through Zinc oxide $+\mathrm{ZnSB}$ & 1130 & 311 & 498 & 54 \\
\hline $\mathbf{T}_{9}$ & $\mathrm{~T}_{3}+75 \% \mathrm{RD}$ of $\mathrm{Zn}$ through Zinc oxide $+\mathrm{ZnSB}$ & 1069 & 286 & 455 & 45 \\
\hline $\mathbf{T}_{10}$ & $\mathrm{~T}_{3}+50 \% \mathrm{RD}$ of $\mathrm{Zn}$ through Zinc oxide $+\mathrm{ZnSB}$ & 1060 & 276 & 451 & 49 \\
\hline $\mathbf{T}_{11}$ & $\mathrm{~T}_{3}+25 \% \mathrm{RD}$ of $\mathrm{Zn}$ through Zinc oxide $+\mathrm{ZnSB}$ & 1007 & 260 & 441 & 43 \\
\hline \multicolumn{2}{|c|}{ S.E.m \pm} & 19.90 & 4.13 & 8.58 & 0.74 \\
\hline \multicolumn{2}{|c|}{ CD at $5 \%$} & 59.11 & 12.26 & 25.47 & 2.19 \\
\hline
\end{tabular}

Table.6 Effect of application of zinc fertilizer and zinc solubilzing bacteria on pod and haulm Yield

\begin{tabular}{|c|c|c|c|c|}
\hline $\begin{array}{l}\text { Tr. } \\
\text { No }\end{array}$ & Treatment & 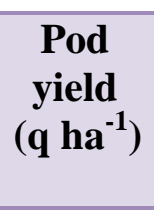 & $\begin{array}{l}\text { Haulm } \\
\text { yield } \\
\left(\mathbf{q} \text { ha }^{-1}\right)\end{array}$ & $\begin{array}{l}\text { Per cent } \\
\text { increased } \\
\text { pod yield } \\
\text { over } T_{3}\end{array}$ \\
\hline $\mathbf{T}_{1}$ & Absolute control & 20.82 & 42.50 & - \\
\hline $\mathbf{T}_{2}$ & ZnSB alone & 21.77 & 44.20 & - \\
\hline $\mathbf{T}_{3}$ & 100\% GRDF (25:50 kg ha $\left.{ }^{-1} \mathrm{~N}: \mathrm{P}_{2} \mathrm{O}_{5}+\mathrm{FYM} @ 5 \mathrm{tha}^{-1}\right)$ & 26.56 & 62.70 & - \\
\hline $\mathbf{T}_{4}$ & $\mathrm{~T}_{3}+100 \% \mathrm{RD}$ of $\mathrm{Zn}$ through Zinc sulphate $+\mathrm{ZnSB}$ & 30.63 & 58.90 & 15.32 \\
\hline $\mathbf{T}_{5}$ & $\mathrm{~T}_{3}+75 \%$ RD of $\mathrm{Zn}$ through Zinc sulphate $+\mathrm{ZnSB}$ & 29.44 & 53.72 & 10.84 \\
\hline $\mathbf{T}_{6}$ & $\mathrm{~T}_{3}+50 \% \mathrm{RD}$ of $\mathrm{Zn}$ through Zinc sulphate $+\mathrm{ZnSB}$ & 27.41 & 48.60 & 3.20 \\
\hline $\mathbf{T}_{7}$ & $\mathrm{~T}_{3}+25 \%$ RD of $\mathrm{Zn}$ through Zinc sulphate $+\mathrm{ZnSB}$ & 26.65 & 45.90 & 0.33 \\
\hline $\mathbf{T}_{8}$ & $\mathrm{~T}_{3}+100 \% \mathrm{RD}$ of $\mathrm{Zn}$ through Zinc oxide $+\mathrm{ZnSB}$ & 27.22 & 50.42 & 2.48 \\
\hline $\mathbf{T}_{\mathbf{9}}$ & $\mathrm{T}_{3}+75 \% \mathrm{RD}$ of $\mathrm{Zn}$ through Zinc oxide $+\mathrm{ZnSB}$ & 27.06 & 47.34 & 1.88 \\
\hline $\mathbf{T}_{10}$ & $\mathrm{~T}_{3}+50 \% \mathrm{RD}$ of $\mathrm{Zn}$ through Zinc oxide $+\mathrm{ZnSB}$ & 26.90 & 46.91 & 1.28 \\
\hline $\mathbf{T}_{11}$ & $\mathrm{~T}_{3}+25 \% \mathrm{RD}$ of $\mathrm{Zn}$ through Zinc oxide $+\mathrm{ZnSB}$ & 26.41 & 44.98 & 1.43 \\
\hline \multicolumn{2}{|c|}{ S.Em+ } & 0.478 & 1.027 & \\
\hline \multicolumn{2}{|c|}{ CD at $5 \%$} & 1.42 & 3.05 & \\
\hline
\end{tabular}

The total uptake of $\mathrm{Fe}$ was found to be significantly higher in $\mathrm{T}_{4}$ treatment $(1352$ gha $\left.^{-1}\right)$ over all the treatment except $\mathrm{T}_{3}(1344 \mathrm{~g}$ $\mathrm{ha}^{-1}$ ) which was at par with $\mathrm{T}_{4}$. Total uptake of $\mathrm{Zn}$ significantly higher in treatment of $\mathrm{T}_{4}$ $\left(377 \mathrm{~g} \mathrm{ha}^{-1}\right)$ over all the treatment. Amalraj et 
al., (2012) also reported increase in zinc uptake by soybean due to seed inoculation of PSB and solubilizers. The total uptake of Mn was significantly increased in $\mathrm{T}_{4}$ treatment (619 $\mathrm{g} \mathrm{ha}^{-1}$ ) over all the treatment except treatment $\mathrm{T}_{3}\left(598 \mathrm{~g} \mathrm{ha}^{-1}\right)$ which was at par with $\mathrm{T}_{4}$ in respect of $\mathrm{Mn}$ uptake. This might be due to exudation of phytase which is important for Mn uptake from high $\mathrm{pH}$ soils. Similar results were also observed by George et al.,( 2014).The total uptake of $\mathrm{Cu}$ was observed significantly higher in $\mathrm{T}_{4}\left(67 \mathrm{~g} \mathrm{ha}^{-1}\right)$ over all the treatment. The zinc sulphate treatment was higher than the other treatment. Gururmurthy et al., (2009) reported increase in uptake in grain and straw with $\mathrm{N}, \mathrm{P}$ and $\mathrm{K}$ application of PSB to soybean.

\section{Pod and haulm yield}

Pod and haulm yield of groundnut as influenced by different treatments are presented in table 6 The pod yield of groundnut was found to be significantly increased $\left(30.63 \mathrm{q} \mathrm{ha}^{-1}\right)$ in treatment of $\mathrm{T}_{4}$ over all the treatment except treatment $\mathrm{T}_{5}$ (29.44 $\mathrm{q} \mathrm{ha}^{-1}$ ) which was at par. Overall, the per cent increased in treatments of application of $\mathrm{ZnSO}_{4}+\mathrm{ZnSB}$ were found higher in pod and haulm yield of groundnut as compare to treatments of application of $\mathrm{ZnO}+\mathrm{ZnSB}$. Application of zinc in soil resulted in increased in yield of groundnut was in the range of 15.32 to $0.33 \%$ in treatments of soil application of $\mathrm{ZnSO}_{4}$ over GRDF $\left(\mathrm{T}_{3}\right)$.

The haulm yield of groundnut was found to be significantly increased $\left(62.70 \mathrm{q} \mathrm{ha}^{-1}\right)$ in treatment of GRDF $\mathrm{T}_{3}$ over all the treatments under study. However, the treatments of application of $\mathrm{ZnSO}_{4}+\mathrm{ZnSB}$ were increased in pod and haulm yield of groundnut as compare to treatments of application of $\mathrm{ZnO}$ $+\mathrm{ZnSB}$. Application of zinc in soil resulted in increased in yield of groundnut was reported by Talukdar and Islam (1982).
From the above findings, It is concluded that, the application of $100 \%$ recommended dose of Zn through Zinc sulphate @ $20 \mathrm{~kg} \mathrm{ha}^{-1}+$ $5 \% \mathrm{ZnSB}$ to seed treatment at sowing and through drenching at 30 DAS along with 100 $\%$ (25:50:0 kg ha ${ }^{-1} \mathrm{~N}: \mathrm{P}_{2} \mathrm{O}_{5}: \mathrm{K}_{2} \mathrm{O}+\mathrm{FYM} @ 5 \mathrm{t}$ $\mathrm{ha}^{-1}$ ) to summer groundnut was found beneficial for increased in available macro and micronutrients status of soil, total uptake of macro and micronutrient and pod yield of groundnut in Entisol.

\section{References}

Amalraj, D.L., Maiyappan, S. and John Peter, A. (2012) In vivo and In vitro studies of Bacillus megaterium var. phosphaticum on nutrient mobilization, antagonism and plant growth promoting traits. Journal Eco-Biotechnology, 4, $35-42$.

Ashoska, Mudalagiriyappa P. and Desai, B.K. (2008) Effect of micronutrients with or without organic manures on yield of baby corn-chickpea sequence.

Karnataka Journal of Agricultural Sciences. 21(4): 485-487.

Bashour, I.I., Prasad, D.J. and Al-Mozroa, M. (1983) Movement of potassium and phosphorus in soil columns. Proceedings of the $6^{\text {th }}$ Conference on the Biological Aspects of Saudi Arabia, King Abdul Aziz University. 33-54.

Chapman, H.D. and Pratt, P.P. (1961) Methods of analysis for soil, plant and water. Division of Agricultural Science, California University, USA pp. 309.

Fasim, F., Nuzhat, A., Richard, P. and Gadd, G.M. (2002) Solubilization of zinc salts by a bacterium isolated from the air environment of a tannery. FEMS Microbiology, 213, 1-6.

George, T.S., French, A.S., Brown, L.K., Karley, A.J., White, P.J., Ramsay, L., Daniell, T.J. (2014) Genotypic variation in the ability of landraces and 
commercial cereal varieties to avoid manganese deficiency in soils with limited manganese availability: is there a role for root-exuded phytases? Physiologia Plantarum, 151, 243-256.

Gurumurthy, K.T., Leena Narayan and Prakasha, H.C. (2009) Micronutrient uptake and yield of soybean (Glycine $\max$ (L) Merrill) as influenced by integrated nutrient management practices. Mysore Journal of Agriculture Science, 23, 883-886.

Hutchins, M.N., Davidson, M.S., Brierey, C.L., (1986) Microorganisms in reclamation of metals. Annual Review of Microbiology, 40, 311-336.

Javid, S. and D.L. Rowell, 2003. Assessment of the effect of time and temperature on the availability of residual phosphate in a glasshouse study of four soils using the olsen method. Soil Use Management, 19: 243-249.

Kayalvizhi, C., Gopal, H., Baskar, M., Bose, S.C., Siavan and Ham, M. (2001) Recycling of distillery effluent in agriculture effect on soil properties and sugarcane yield. $63^{\text {rd }}$ Annual Convention of the Sugar Technologists Association of India, Aug 25-27, New Delhi. pp. 153.

Kumar, R.N., Arasu, V.T. and Gunasekaran, P. (2002) Genotyping of antifungal compounds producing plant growth promoting rhizobacteria, Pseudomonas fluorescens. Current Science, 82, 1463 1466.

Lindsay, W.L. and Norvell, W.L. (1978) Development of DTPA soil test for Zn, $\mathrm{Fe}, \mathrm{Mn}$ and $\mathrm{Cu}$. Soil Science Society of America Journal, 42, 421-428

Lugtenberg, B. and Kamilova, F. (2009) Plant Growth-Promoting Rhizobacteria. Annual Review of Microbiology, 63, 541-556.

Manna, M. C., Subba Rao, A. and Ganguly, T. K. (2007) Effect of fertilizer P and
FYM on bioavailable $\mathrm{P}$ as influenced by rhizosphere microbial population in soybean-wheat rotation. Journal of Sustainable Agriculture, 29, 149-166.

Morshedi, A. and Farahbakhsh, H. (2010) Effects of potassium and zinc on grain protein contents and yield of two wheat genotypes under soil and water Environment, 104, 509-522.

Potarzycki, J. and Grzebisz, W. (2009) Effect of zinc, foliar application on grain yield of maize and its yielding components. Plant Soil Environment, 55, 519-527.

Simine Di., Sayer, J.A. and Gadd, G.M. (1998) Solubilization of zinc phosphate by a strain of Pseudomonas fluroscens isolated from a forest soil. Biology and Fertility of Soils, 28, 87-94.

Stark, J.C. and Westermann, D.T. (2003) Nutrient Management. In: Potato Production Systems, Stark, J.C. and S.L. Love (Eds.). University of Idaho Agricultural Communications, Moscow, ID, pp: 115-135.

Stein, A.J. (2010) Increase the availability of micronutrients especially $\mathrm{Zn}$ and $\mathrm{Fe}$ in the major food crops. Journal of Plant Nutrition335, 133-154.

Steinshamn, H., Thuen, E., Bleken, M.A., Brenoe U.T., Ekerholt, G. and Yri, C. (2004) Utilization of nitrogen and $P$ in an organic dairy farming system in Norway. Agriculture Ecosystem Environment, 104, 509-522.

Subbiah, B.V. and Asija, G.L. (1956) A rapid procedure for the estimation of available nitrogen in soils. Current Science, 25, 259-260.

Sukhatme, P.V. and Panse, V.G. (1985) Statistical method for Agriculture Workers, Revised Edn. ICAR. New Delhi.

Tilak, K.V.B.R., Singh, C.S., Roy, N.K. and Subba Rao, N.S. (1982) Azospirillum brasilense and Azotobacter chroococcum inoculums: Effect on 
yield of maize (Zea mays) and sorghum (Sorghum bicolor). Soil Biology and Biochemistry, 14, 417-418.

Tilman, D. (1998) The greening of the green revolution. Nature. 396, 211-212.

Vikram, A., Algawadi, A.R., Hamzehzarghani, H. and Krishnaraj, P.U. (2007) Factorrelated to the occurrence of phosphate solubilising microorganisms and their isolation in vertisol. International Journal of Agricultural Research, 2, 571-580.

Wissuwa, M., Ismail, A.M. and Yanagihara, S. (2006) Effects of zinc deficiency on rice growth and genetic factors contributing to tolerance. Journal of Plant Physiology, 142, 731-741.

\section{How to cite this article:}

Raut, A.D., A.G. Durgude, A.D. Kadlag, M.V.V.I. Annapurna and Chauhan, M.R. 2019. Potential of Plant Growth Promoting Bacteria on Nutrient Availability in Soil, Nutrient Uptake and Yield of Summer Groundnut Grown on Entisol. Int.J.Curr.Microbiol.App.Sci. 8(02): 23262335. doi: https://doi.org/10.20546/ijcmas.2019.802.271 